\title{
A TELJESÍTMÉNYÉRTÉKELÉS ÉS VISSZAJELZÉSEK ÖSSZEFÜGGÉSEI A KARRIERSIKERREL
}

\author{
Szondi Réka - Gergely Éva
}

\begin{abstract}
Absztrakt: A teljesítményértékelés megjelenése nem újkeletü, már az 1900-as években is megfogalmazták a jelentőségét a klasszikus vezetési iskolák képviselői. A HR funkciók rendszerében a hagyományos funkciók közé soroljuk, melyre számos más tevékenység épül. Valamilyen formában jelen van minden szervezet müködésében, akár formális, akár informális módon. Az értékelés akkor müködik jól, ha nem számonkérö és büntető jellege van, hanem motiválja, ösztönzi az embereket. A kutatás célja a teljesítményértékelés és a visszajelzés elemzése, valamint a munkavállalókban kialakuló karriersiker érzésével való összefüggésének vizsgálata. Napjainkban a koronavírus kapcsán lényeges tényező a munka körülményeiben történő változás és az ezáltal tapasztalt bizonytalanságok, melyek miatt még inkább felerősödik a teljesítményértékelés jelentősége. A kutatás következtetései a saját kérdőív eredményein alapszanak, mely szerint elmondható, hogy a teljesítményértékelés napjainkban is központi szerepet tölt be. A rendszeres visszajelzés ösztönzőleg hat, motivál és a munkavállalók által elvárt a fejlődéshez. A megfelelően működtetett teljesítményértékelési rendszer segíti a karrierfejlődést, az elkötelezettséget és egyesíti az egyéni célokat a stratégiai, szervezeti célkitüzésekkel.
\end{abstract}

\begin{abstract}
The appearance of performance appraisal is not new; as early as the 1900s, classical management theories' representatives expressed its importance. In the HR functions system, we classify them as traditional functions, on which many other activities are based. It is present in some form in the functioning of every organisation, whether formally or informally. Appraisal works well if it is not accountable and punitive but motivates and encourages people. The research aims to analyse performance appraisal and feedback and the coherence with career success in employees. A significant factor concerning the coronavirus is the change in working conditions and the resulting uncertainties, further increasing the importance of performance appraisal. The research conclusions are based on our questionnaire results, according to which it can be said that performance appraisal still plays a central role today. Regular feedback is encouraging, motivating and expected by employees for development. A properly functioning performance appraisal system helps with career development, commitment, and combines individual goals with strategic, organisational goals.
\end{abstract}

Kulcsszavak: teljesítményértékelés, visszajelzés, karrier, karriersiker, HR

Keywords: performance appraisal, feedback, career, career success, HR

\section{Bevezetés}

A teljesítménymenedzsmentnek egy részeként tekintünk a teljesítményértékelésre, illetve mérésre, melynek célja, hogy biztosítsa a szervezeti oldalon kitüzött eredményeket. E tekintetben lényeges szempont a célok azonosként való értelmezése a szervezet minden tagja számára. Az egyértelmủ célkitüzések megalapozzák azok könnyebb megértését és annak megvalósulását, hogy az egyén a magáénak tekintse ezeket a célokat, ezáltal érvényesítve az egyéni és szervezeti érdekeket egyaránt (Gergely, 2016). Az elvárások és az ezek eléréséhez szükséges támogatáson, a képességek meglétén és az ösztönzésen túl nem elhanyagolható a teljesítmény alakulásának nyomon követése, a folyamatos ellenőrzés, amivel a hibák minimalizálhatóak (Gyökér-Finna, 2007). 
Fajcikova és szerzőtársai (2018) több mint 300 szervezetet felölelő vizsgálatukban kapcsolatot találtak a karriermenedzsment, képzések, fejlesztések, teljesítményértékelés és az ösztönzés között. Dajnoki és Héder (2017) tanulmányában a HR funkciók bővülésével összefüggésben szintén leírják az emberi erőforrások fejlesztése, a karriermenedzsment és a teljesítménymenedzsment fontosságát és kapcsolódását az integrált szemléletmód hangsúlyozása mellett. A teljesítmény és a karrier több kutatás során is egymásra ható tényezőkként definiált. Szabó-Bálint (2018) elemzésében a különböző karriermenedzsment eszközök között is megjelenik a teljesítményértékelés, mint a karriertervezés alapja (Baruch-Peiperl, 2000; Lewis-Arnold, 2012). Ideális esetben a vállalati és a HR stratégia is alkalmazkodik a munkaeröpiacon bekövetkező változásokhoz, hiszen így tud időben reagálni. Míg évekkel ezelött a tehetséges munkavállalók bevonzása volt a fontos, napjainkra egyre több figyelem hárul a dolgozók elkötelezetté tételére. Egy 2017-es kutatás alapján (HRportál, 2017), a vizsgált 150 ország munkavállalóinak csak 15\%a elkötelezett a munkahelye és munkáltatója iránt, ami igen alacsony arány. A Randstad Employer Brand Research 2020-as felmérése (Piac és profit, 2020) a hazai munkahelyválasztási preferenciákat vizsgálta, az eredmények alapján pedig kiemelt helyet kapott a vonzó jövedelem és a juttatás, a kellemes munkahelyi légkör és a biztos állás. Az elkötelezettség kialakításához a magas teljesítmény és a lojalitás összehangjára van szükség (Istók, 2019), amely a megfelelő visszajelzések és az elvárások és lehetőségek egyértelmüsítése nélkül valószínütlen. A munkavállalók sokszínüek, eltérő generációk dolgoznak együtt, nem ugyanaz a vonzó mindenkinek (Pierog et al., 2018). Ezért is lényeges a lehető legnagyobb mértékben egyénre szabni, a munkavállalóhoz igazítani a szervezet motivációs eszköztárát a szervezeti és egyéni célokkal összhangban (Dajnoki-Kun, 2016; Krajcsák, 2018; Kubiak, 2020). A karriermenedzsment vonatkozásában már Orphen (1994) eredményei is összefüggést mutattak abban, hogy ha a szervezet támogatja a munkavállalói fejlesztését, akkor nem meglepő, hogy azok sikeresek lesznek és elkötelezettebbnek is bizonyulnak.

A karriersiker, sikeresség kérdéskörben több szempontból elfogadott Arthur és szerzőtársai (2005) definíciója, mely szerint a sikert az egyén munkatapasztalatainak eredményeként definiálják, a karriersikert pedig a munkatapasztalatok során valamely időpontban elért pozitív kimenetelt. A karriersiker azonban leírható objektív és szubjektív mutatókkal is (Judge et al., 1995). Az objektív vagy külső karriersikerhez sorolható a jövedelem, a magas presztízs, befolyásos pozíció megléte, előmenetel, fejlődés, elismerés, tisztelet, míg a szubjektív vagy belső karriersiker gyakran az egyén érzéseiben jelenik meg például örömként (Koncz, 2013a). Koncz (2013a; 2013b) szerint az egyéni karrierigényekre való odafigyelés, az ösztönzés és a tudáspotenciál kihasználásába fektetett idő és pénzeszközök hozzájárulnak a szervezeti teljesítmény növekedéséhez is. A magas potenciállal rendelkező személyeket nem elég bevonzani, megfelelően kell közvetíteni feléjük a szervezeti értékeket, a látásmódot, víziót és a célokat, az egyéni és a szervezeti érdekeket összekapcsolva (Erdei et al., 2017). Dajnoki és Filep (2020) új kutatási irányként határozza meg a KKV-k körében a nem pénzügyi mutatók használatát és 
vizsgálatát a szervezeti teljesítménymérésben, ide sorolva a dolgozói elégedettséget is.

Az elöregedő társadalom miatt csökken a munkavállalói réteg és a munkavállalókkal szemben támasztott szervezeti igények mellett figyelni kell a másik oldal elvárásainak bővülésére is (Canton, 2013). Kiss és Barizsné (2018) kutatásukban pozitív kapcsolatot találtak a munkahelyi elégedettség és a szakmai illeszkedés között, alátámasztva ezzel a megfelelő ember elhelyezését a megfelelő helyre elvet (Dajnoki et al., 2015), egyéni és szervezeti oldalról is egyaránt. Bálint és Karoliny (2017) megemlíti, hogy szükség van a szervezeti szerepvállalásra, ha az egyén karrierjét gondozzuk, ám a siker felfogása egyénenként különböző lehet. Héder és szerzőtársai (2018) az emberi erőforrás menedzsment kapcsán összegzik annak legfontosabb összetevőit: szervezeti oldalról a célok kielégítése, biztosítani a megfelelö munkakörnyezetet, az emberi erőforrások kapacitásának folyamatos növelése, egyéni oldalról pedig az egyéni igények, képzések, fejlesztések és a munkavállalók megtartása a legfontosabb. Ha azonban az egyéni tudás és potenciál nem lesz megfelelően kihasználva és a vezetőségtől jövő támogatás hiánya is elmarad, az innovációs készség és a kreativitás (mint a szervezeti versenyképességet jelentős mértékben befolyásoló tényezők) negatív megerősítést kaphat (GergelyPierog, 2018; Li-Ying et al., 2018). Pirohov-Tóth (2019) dolgozói elégedettség és szervezeti teljesítmény témakörben végzett kutatásában kiemeli a vezetői szerepeket és kompetenciákat, illetve a túlszabályozás hátrányait, melynek hatása van a dolgozók kreativitására és kezdeményezőkészségére. A kreativitást elősegítheti, ha azok, akik igénylik, gyakori visszajelzést kapnak a feletteseiktől (Lee-Kim, 2021). Ha bevonják őket a döntéshozatalba (empowerment) bizonyos kérdésekben, akkor növelhető az elkötelezettség és jobban magukénak érzik a szervezeti célokat is.

\section{Anyag és módszer}

A kérdőív kitöltői magyarországi telephelyü vállalatok szellemi munkavállalói voltak. A kérdőív összeállítása során a feldolgozott szakirodalomra és saját ötleteinkre támaszkodtunk. A primer adatgyüjtés időszaka 2020. novemberdecember és 2021. január, a részvétel minden esetben önkéntes és anonim volt. Az interjúk online térben történtek a COVID-19 járványhelyzet miatt, a kérdőívekhez a Google Forms felületet használtuk. Az alanyokat kapcsolati hálónk adta, a kitöltők hólabda módszerrel növelték az elérést. Szempont volt, hogy minél több szektor és vállalati méret és korosztály képviseltesse magát. A kérdőív lezárásakor 72 értékelhető kitöltés állt a rendelkezésünkre, a tanulmányban ezek feldolgozása történt meg.

Az alábbiakban a kérdőív kitöltőinek demográfiai adatai olvashatók. A kérdőív kitöltése során a válaszadóknak nyolc csoportképző kérdést kellett megválaszolniuk, melyböl hét eredményét szemlélteti az 1. táblázat.

A minta szürésénél és kiválasztásánál lényeges szempont volt, hogy szellemi munkavállalók töltsék ki a kérdőívet. A minta nem reprezentatív jellegü. A kitöltők között nagyobb arányban vannak a nők (58fö), mint a férfiak (14fó). Életkor alapján a legnagyobb csoport a 26-33 éves korosztály, végzettséget tekintve a diplomások 
vannak többen. A beosztás, illetve a szektor szerint is diverzifikáltak a kitöltők. A vállalatok telephely szerint öt régióban helyezkednek el vegyesen, legnagyobb arányban az Észak-Alföld (31), Észak-Magyarország (12) és Közép-Magyarország (27) területéröl voltak a kitöltők (NUTS-2 régiók besorolása alapján). 1-1 kitöltő volt a Dél-Alföld és Nyugat-Dunántúl régiókból. A válaszadók legnagyobb része középvállalatban dolgozik, ezt követi szorosan a nagyvállalati szektor, de megtalálható a mintában a kis- és mikrovállalkozás is. A kitöltők diverzitása miatt a kapott eredmények többlet információt adnak, ám egyes kérdéscsoportoknál torzító hatása is lehet a különbözőségnek. Az eredmények minden esetben csak a kitöltőkre vonatkoztathatók, nem általánosíthatók a magyar lakosságra.

\section{1. táblázat: A válaszadók demográfiai jellemzői}

\begin{tabular}{|c|c|c|c|}
\hline Azonosító adatok & $\begin{array}{c}\text { Teljes minta } \\
(n=72) \text { fó }\end{array}$ & Azonosító adatok & $\begin{array}{c}\text { Teljes minta } \\
(n=72) \text { fó }\end{array}$ \\
\hline Nem & & \multirow{8}{*}{$\begin{array}{l}\text { Iskolai végzettség } \\
\text { Szakközépiskola } \\
\text { Gimnázium } \\
\text { OKJ felsőfokú képzés } \\
\text { Főiskolai diploma (BA, BSc) } \\
\text { Egyetemi diploma (MA, MSC) } \\
\text { PhD fokozat } \\
\text { MBA }\end{array}$} & \\
\hline Nő & 58 & & 4 \\
\hline Férfi & 14 & & 2 \\
\hline Életkor (év) & & & 3 \\
\hline $18-25$ & 5 & & 18 \\
\hline $26-33$ & 25 & & 37 \\
\hline $34-41$ & 16 & & 6 \\
\hline $42-49$ & 14 & & 2 \\
\hline 50 év és felette & 12 & \multirow{5}{*}{$\begin{array}{l}\text { Jelenlegi beosztása } \\
\text { Felsővezető } \\
\text { Középvezető } \\
\text { Alsóvezető } \\
\text { Beosztott } \\
\end{array}$} & \multirow{5}{*}{$\begin{array}{r}6 \\
17 \\
9 \\
40\end{array}$} \\
\hline Szervezeti méret & & & \\
\hline Mikrovállalat (1-9 fö) & 5 & & \\
\hline Kisvállalat (10-49 fö) & 12 & & \\
\hline Középvállalat (50-249 fó) & 28 & & \\
\hline Nagyvállalat (250 fö felett) & 27 & \multirow{5}{*}{$\begin{array}{l}\text { Szektor } \\
\text { Ipar } \\
\text { Kereskedelem } \\
\text { Szolgáltatás } \\
\text { Közszféra } \\
\end{array}$} & \multirow{5}{*}{$\begin{array}{r}11 \\
3 \\
45 \\
13\end{array}$} \\
\hline Tulajdonosi szerkezet & & & \\
\hline Magyar tulajdonú & 45 & & \\
\hline Külföldi tulajdonú & 25 & & \\
\hline Vegyes tulajdonú & 2 & & \\
\hline
\end{tabular}

Forrás: A Szerzők saját szerkesztése (2021)

A kérdőív felépítését tekintve vegyes típusú kérdéseket tartalmaz. Az azonosító adatok, csoportképző kérdések mellett, Likert-skálás kérdéseket tartalmazott nagyobb részben. A skálás kérdésekhez 7-fokozatú besorolást használtunk, a nagyobb differenciálás érdekében. Az legalacsonyabb végpont (1) az „Egyáltalán nem értek egyet”, a skála másik végpontja (7) pedig a „Teljes mértékben egyetértek” jelzőket kapta. Így lehetőség volt a középérték (4) „Semleges” jelölésére is. A Kolmogorov-Smirnov normalitás vizsgálat során kiderült, hogy a minta eloszlása nem tekinthető normálisnak. Az eredményekhez a leíró statisztika mellett Spearmanféle rangkorrelációt alkalmaztunk.

\section{Eredmények}

Az elemzés során a teljesítményértékeléshez sorolt skálás kérdések, majd a korrelációs kapcsolatok értékelése történt meg a karriersiker és a teljesítmény 
összefüggésében. A kutatásban a formális és informális értékelés gyakorisága, illetve az értékelők köre is fontos szerepet kapott. Az alábbiakban az adatok elemzése és értékelése olvasható.

\subsection{A teljesítményértékeléshez tartozó skálás kérdések elemzése}

Az eredmények a kérdőívet kitöltők véleményére vonatkoznak, nem tekinthetők általánosnak és reprezentatívnak. A kérdőív elején közérthetően feltüntettük a teljesítményértékelés és a visszajelzés értelmezését, ezzel is könnyítve a kitöltést és az egyéni értelmezésből eredő torzításokat. A kérdőív elején különböző állításokat kellett értékelniük a kitöltőknek egy 7-fokozatú Likert-skálán, melynél az 1-es érték az „Egyáltalán nem értek egyet”, a 7-es érték a „Teljes mértékben egyetértek”. Az állítások egy részét szemlélteti a 2. táblázat.

\section{2. táblázat: Likert-skálás állítások átlag és szórásértéke}

\begin{tabular}{|l|r|r|}
\hline Állítások & Átlag & Szórás \\
\hline 1.) Számomra fontos a visszajelzés a munkavégzésemröl. & 6,69 & 0,81 \\
\hline 2.) A kapott visszajelzés legyen rendszeres. & 6,01 & 1,18 \\
\hline 3.) A teljesítményértékelés számomra elég évente. & 2,94 & 1,86 \\
\hline 4.) A gyakori visszajelzés motivál. & 5,70 & 1,37 \\
\hline $\begin{array}{l}\text { 5.) Nem fordul elö, hogy egy hibám alapján ítélnek meg az adott } \\
\text { időszakban. }\end{array}$ & 4,40 & 1,82 \\
\hline 6.) Az eddigi értékeléseket reálisnak tartom. & 5,47 & 1,43 \\
\hline 7.) Az értékelés után tudom, miben kell fejlödnöm. & 5,72 & 1,46 \\
\hline 8.) Az értékelést mindig várom, szeretek visszajelzést kapni. & 5,86 & 1,41 \\
\hline 9.) Az értékelés kellemes, nem szoktam feszült lenni elötte. & 4,94 & 1,76 \\
\hline 10.) Sikeresnek érzem magam a munkámban. & 5,75 & 1,39 \\
\hline 11.) A visszajelzések ösztönzöleg hatnak rám. & 5,95 & 1,35 \\
\hline 12.) Gyakran dicsérnek meg a munkahelyemen. & 5,06 & 1,80 \\
\hline 13.) Elvárom, hogy visszajelzést kapjak a teljesítményemröl. & 6,18 & 1,13 \\
\hline $\begin{array}{l}\text { 14.) A teljesítményértékelés végén megfogalmazódnak } \\
\text { jövőbeli célok, elvárások. }\end{array}$ & 5,81 & 1,31 \\
\hline $\begin{array}{l}\text { 15.) Tisztában vagyok minden feladattal, ami a munkakörömbe } \\
\text { tartozik. }\end{array}$ & 5,72 & 1,73 \\
\hline $\begin{array}{l}\text { 16.) Aki engem értékel, jól meg tudja ítélni a munkafeladataim } \\
\text { elvégzését. }\end{array}$ & 5,12 & 1,81 \\
\hline 17.) A jelenlegi munkavégzésem sikerként élem meg. & 5,76 & 1,41 \\
\hline 18.) Szeretem a munkám. & 6,19 & 1,04 \\
\hline 19.) Tudatosan tervezem a karrierem. & 5,46 & 1,24 \\
\hline 20.) A karrieremért a vezető a felelős. & 3,04 & 1,74 \\
\hline 21.) Én vagyok felelős a karrieremért. & 6,10 & 1,21 \\
\hline
\end{tabular}

Forrás: A Szerzők saját szerkesztése (2021)

Valamennyi állítás a 2. táblázatból a skála pozitív oldalára tehető, két kivétellel. Legmagasabb átlagértéket a visszajelzés fontossága kapta $(6,69)$ és itt a 
legalacsonyabb a szórásérték is. Hasonló magas értéket képvisel a visszajelzés a teljesítményről és ennek rendszeressége, ezzel is alátámasztva a jelentőségét. A rendszerességgel kapcsolatban, legalacsonyabb értékü $(2,94)$ a „A teljesítményértékelés számomra elég évente." item, ami alapján a kitöltők az ennél gyakoribb alkalmakat preferálják. A szórásértékek intervalluma 0,81-től 1,86-ig terjed, aminek hátterében a kitöltők alacsonyabb száma is állhat. Hasonló átlagpontokat láthatunk „A gyakori visszajelzés motivál.”, „Az értékelést reálisnak tartom.” és „Az értékelés után tudom, miben kell fejlődnöm.” állításoknál, ami a kitöltők által tapasztalt pozitív értékelést erősíti. Érdekes továbbá az utolsó két állítás, melyek egymás ellentettjei. A kitöltők válaszai alapján, saját magukat nagyobb mértékben tartják felelősnek egyéni karrierjükért, mint a vezetőjüket. A válaszadók többsége tudatosan tervezi a karrierjét is. Szabó-Bálint és Karoliny (2019) tanulmányukban megállapítják, hogy habár az egyénnek van felelössége a karriersiker elérésében, a szervezetnek mégis fontos szerepe van a dolgozók sikerében.

A kitöltők oldaláról elmondható, hogy a teljesítményértékelést és a visszajelzéseket szükségesnek tartják, annak rendszerességének és minőségének jelentőséget tulajdonítanak. Fontos továbbá a teljesítményt megítélő személye, az elvárások egyértelmüsége és a visszajelzések ösztönző hatása.

3.2. Korreláció, a formális és informális értékelés, illetve az értékelők körének elemzése

A 2. táblázatban szereplő Likert-skálás állítások összefüggéseihez Spearman-féle rangkorreláció elemzést készítettünk. A korrelációértékeket 0 (nincs lineáris kapcsolat) és 1 (nagyon erős, függő kapcsolat) között értelmeztük (I1). A 3. táblázat a nyolc legerősebb korrelációs kapcsolatot ábrázolja. Az egyes állításpárok korrelációs együtthatója közepes (0,552-töl 0,658 -ig), illetve erős $(0,701)$ kapcsolódást mutat. Az első állításpárnál látható a tudatos karriertervezés és a munkában érzett sikeresség kapcsolódása. A karrierút tudatos tervezése, a célok kitüzése és a lehetőségek kihasználása eredményezi a siker érzését, ami sokszor párosul elkötelezettséggel is. A második párnál, az értékelés során megfogalmazott fejlődési utak, célok és elvárások összhangja figyelhető meg. A harmadik pár korrelációjának értelmezése, a gyakori informális és formális visszajelzés generálta siker érzés a munkavállalóban. Az 5,90 együtthatóval rendelkező negyedik item-pár azt mutatja meg, hogy ha az értékelő személye megfelelő, reálisan és objektíven fel tudja mérni az értékelt teljesítőképességét, akkor maga az értékelés nem generál feszültséget a munkavállalóban. Értelemszerúen ehhez az is szükséges, hogy az értékelés előtt az egyén tudja az értékelési időszak alatti nyújtott saját tevékenységét az elvárásoknak megfelelöen megítélni, az önértékelése rendben legyen.

A 3. táblázat erősebb korrelációi is alátámasztják az értékelés és a visszajelzések fontosságát. Míg a nagyobb volumenü, egész szervezetet érintő teljesítményértékelés a legtöbb vállalatnál évente vagy évente kétszer történik, a munkavállalók szempontjából a gyakoribb visszajelzésnek van nagyobb jelentősége, hiszen ez sokszor hathat ösztönzőleg a hétköznapok során vagy a leterheltebb 
időszakokban. A visszajelzéseknek ezt az ösztönző, motiváló hatását igazolja a hatodik állításpár is, 0,629-es korrelációs együtthatójával. A hetedik párnál, az értékelések reálissága és a munkakörre, feladatokra megfelelő mértékben rálátó értékelő közötti kapcsolódást értelmezhetjük. Az utolsó állításpárnál a korrelációs együttható alapján $(0,701)$ magas korrelációról és markáns kapcsolódásról beszélhetünk. A karrier tudatos tervezése és a siker érzése tehát többféleképpen megfogalmazott állítások esetén is összefüggést mutat. Ha a szervezet segíti a munkavállalóját, lehetőségeket tárva elé, akkor az egyén meg tudja valósítani a saját karriercéljait, úgy, hogy eközben a szervezeti célokért is tesz. Ha a munkavállaló sikeresnek és megbecsültnek érzi magát a munkájában, kisebb a valószínűsége a fluktuációnak és nagyobb az esélye az elkötelezettség kialakulásának.

\section{3. táblázat: Korrelációs kapcsolatok a Likert-skálás elemek között}

\begin{tabular}{|l|l|l|c|}
\hline \multicolumn{2}{|c|}{ Állításpárok } & $\begin{array}{c}\text { Korrelációs } \\
\text { együttható* }\end{array}$ \\
\hline 1. & $\begin{array}{l}\text { Sikeresnek érzem magam } \\
\text { a munkámban. }\end{array}$ & Tudatosan tervezem a karrierem. & 0,552 \\
\hline 2. & $\begin{array}{l}\text { Az értékelés után tudom, } \\
\text { miben kell fejlödnöm. }\end{array}$ & $\begin{array}{l}\text { A teljesítményértékelés végén } \\
\text { megfogalmazódnak a jövőbeli célok, } \\
\text { elvárások. }\end{array}$ & 0,562 \\
\hline 3. & $\begin{array}{l}\text { Sikeresnek érzem magam } \\
\text { a munkámban. }\end{array}$ & Gyakran dicsérnek meg a munkahelyemen. & 0,572 \\
\hline 4. & $\begin{array}{l}\text { Az értékelés kellemes, } \\
\text { nem szoktam feszült lenni } \\
\text { elötte. }\end{array}$ & $\begin{array}{l}\text { Aki engem értékel, jól meg tudja ítélni a } \\
\text { munkafeladataim elvégzését. }\end{array}$ & 0,590 \\
\hline 5. & $\begin{array}{l}\text { A gyakori visszajelzés } \\
\text { motivál. }\end{array}$ & $\begin{array}{l}\text { Elvárom, hogy visszajelzést kapjak a } \\
\text { teljesítményemről. }\end{array}$ & 0,617 \\
\hline 6. & $\begin{array}{l}\text { Sikeresnek érzem magam } \\
\text { a munkámban. }\end{array}$ & A visszajelzések ösztönzőleg hatnak rám. & 0,629 \\
\hline 7. & $\begin{array}{l}\text { Az eddigi értékeléseket } \\
\text { reálisnak tartom. }\end{array}$ & $\begin{array}{l}\text { Aki engem értékel, jól meg tudja ítélni a } \\
\text { munkafeladataim elvégzését. }\end{array}$ & 0,658 \\
\hline 8. & $\begin{array}{l}\text { A jelenlegi } \\
\text { munkavégzésem } \\
\text { sikerként élem meg. }\end{array}$ & Tudatosan tervezem a karrierem. & 0,701 \\
\hline
\end{tabular}

*A korrelációs együtthatók p $<0,05$ szinten szignifikánsak

Forrás: A Szerzők saját szerkesztése (2021)

A 4. táblázat a kitöltők válaszait mutatja meg, az alapján, hogy milyen gyakran kapnak formális, illetve informális értékelést. Az értelmezés érdekében, a kérdőívben formális jelző mellett a hivatalos, kötött kifejezések, míg az informális mellett a közvetlen, kötetlen szavakat tüntettük fel. A formálisnál megfigyelhető az évente, évente kétszer és a negyedévente válaszok nagyobb aránya. Ám érdekes, és egyben negatív az a 12 eset, mely alapján a formális értékelés ritkábban valósul meg mint évente. Az azonosító adatok alapján ebben vegyesen van KKV és nagyvállalat is. Az informális értékelésre áttérve, a többség a hetente, kéthetente, havonta kategóriákba sorolható, ami véleményünk szerint pozitívnak tekinthető. Akik formális értékelést ritkábban kapnak, mint évente, az informális értékelésre adott 
válaszok alapján többségében a havonta opciót jelölték. A visszajelzés így itt is jelen van, csak annak formája, minősége lehet eltérő.

4. táblázat: Formális és informális értékelések előfordulása

\begin{tabular}{|l|c|c|}
\hline \multicolumn{1}{|c|}{ Opciók } & Formális (n=72) & Informális (n=72) \\
\hline Ritkábban, mint évente & 12 & 2 \\
\hline Évente & 16 & 5 \\
\hline Évente kétszer & 19 & 5 \\
\hline Negyedévente & 15 & 14 \\
\hline Havonta & 5 & 22 \\
\hline Kéthetente & 0 & 11 \\
\hline Hetente & 5 & 13 \\
\hline
\end{tabular}

Forrás: Saját szerkesztés a kérdőív eredményei alapján (2021)

A visszajelzés formája mellett fontos szempont, hogy kitől kapja a munkavállaló a teljesítményére vonatkozó értékelést a szervezetben (Alam-Latham, 2020). Az értékelök körének megjelölésénél több választást is megadhattak a kitöltők (5. táblázat), összesen $138 \mathrm{db}$ választás elemzése történt meg. Szinte minden kitöltőt a közvetlen felettese értékel.

\section{5. táblázat: Értékelők körében adott választások száma}

\begin{tabular}{|l|c|}
\hline \multicolumn{1}{|c|}{ Értékelök köre } & $\begin{array}{c}\text { Választások darabszáma } \\
\text { (össz.:138 db) }\end{array}$ \\
\hline Közvetlen felettes & 69 \\
\hline Felsőbb szintü vezetés & 20 \\
\hline Beosztottja & 10 \\
\hline Munkatársa & 13 \\
\hline Ügyfél & 10 \\
\hline Önértékelés & 13 \\
\hline Humán, HR osztály munkatársai & 3 \\
\hline
\end{tabular}

Forrás: A Szerzők saját szerkesztése (2021)

A kapott válaszok során érdekes volt megfigyelni, hogy míg a kitöltők egy része csak a közvetlen felettestől kap visszajelzést, addig másik részük a közvetlen felettesen kívül akár több forrásból is nyerhet információt. Az értékelők köre függhet attól is, hogy milyen maga az értékelés, mekkora időszakot ölel fel, mit előz meg, milyen teljesítésekhez, teljesítménymutatókhoz kötött.

A 2. táblázatban szereplő állításokra és az értékelők körének választásával (5. táblázat) kapcsolatos kérdésekre elvégzett Khi-négyzet próba egy esetben mutatott ki szignifikáns eltérést. A 16.állítás, „Aki engem értékel, jól meg tudja ítélni a munkafeladataim elvégzését." és a közvetlen felettes, mint leggyakoribb értékelő Khi-négyzet próbája $\mathrm{p}=0,035$ szignifikancia szint mellett mutatott ki eltérést: Khinégyzet $=13,565$. Azok a kitöltők ( 42 fö), akik 6-os és 7 -es értéket adtak a 16. állításra (össz: 5,12 átlagpont), úgy érzik a közvetlen felettesük megfelelően lát rá és értékeli 
a teljesítményüket. A kapcsolat közepesen erösnek ítélhető meg a Cramer-féle asszociációs együttható 0,434 értéke alapján. Az értékelőnek tehát ismernie kell a munkakör által elvárt teljesítménymutatókat, ahhoz, hogy objektíven és reálisan meg tudja ítélni a teljesítményt. Ennek az áttekinthetőbb, gyorsabb megoldása lehet a szabadalomként is jegyzett PaTeNtC JD5TC térbeli munkaköri leírás (Pató-Illés, 2018), ami rendkívül hatékonyan mutatja be a munkakörrel kapcsolatos információkat és adatokat. A kérdőív ezen eredménye alátámasztja, hogy a teljesítményértékelés során milyen fontos az értékelő kiválasztása, az értékelést elvégző ember. Ha ugyanis nincs megfelelő rálátása, akkor a teljesítményértékelés hatékonysága megkérdőjelezhető.

\section{4. Összegzés}

A munkavégzés során szükség van ellenőrzőpontokra, visszacsatolási pontokra, ahhoz, hogy az esetlegesen előforduló hibákról tudomást szerezzünk, illetve hogy megfogalmazhatóvá váljanak a következő időszakra kitüzött célok. Habár kiforrott teljesítménymenedzsment rendszer nincs minden vállalatnál, a teljesítmény mérése és értékelése valamilyen formában jelen van a legtöbb helyen. A kutatás során célunk volt megismerni a teljesítményértékelés és a visszajelzések jelenlétét, azoknak rendszerességét, módját, illetve a karrierrel való összefüggéseit a kitöltők szervezeteinél. A kutatáshoz egy kérdőív készült, az eredmények a kitöltőkre vonatkoztathatók. A kérdőív Likert-típusú állításaihoz hét fokozatú skálát rendeltünk, továbbá több választásos kérdéstípust is alkalmaztunk a csoportképző kérdéseken és az azonosító adatokon kívül. A legmagasabb átlagértéket a visszajelzés fontossága, rendszeressége kapta, itt a legalacsonyabb a szórás is. A Spearman-féle rangkorreláció közepes, illetve erös kapcsolatot igazolt többek között a tudatos karriertervezés és a munkában érzett sikeresség, a gyakori visszajelzés és a siker érzése, ösztönző hatása, továbbá a reális értékelés és az értékelő személye között. Arra a kérdésre, hogy formálisan vagy informálisan milyen gyakorisággal kapnak visszajelzést a válaszadók, vegyes eredmények születtek. A formális értékelésekre a ritkább alkalmak a jellemzőek (évente, évente kétszer, negyedévente), az informálisra pedig a gyakoribbak (havonta, kéthetente, hetente). A kitöltők legnagyobb részét a közvetlen felettesük értékeli, ám sok esetben a felső szintủ vezetés, munkatárs, beosztott és az ügyfelek értékelése is megjelent.

Következtetésképpen elmondható, hogy a teljesítményértékelésre szükség van, jelentősége megkérdőjelezhetetlen. A vizsgálat alatt született kitöltések alapján, a teljesítményértékelésnek szerepe van a siker érzésében, a gyakori, rendszeres visszajelzés motiválóan hat a munkavállalókra. Fontos, hogy a munkavégzést az értékelje, aki reálisan fel tudja mérni a valós teljesítményt, továbbá legyenek kitüzve elvárások és célok a következő értékelési időszakig. Ha a szervezet vezetősége a teljesítményértékelési döntések meghozatalánál bevonja az alkalmazottakat is, nagyobb valószínűséggel mérhetőek fel az egyéni igények, preferenciák. Például, hogy ki, milyen gyakorisággal és milyen módon igényli a visszajelzést a munkavégzésére. A megfelelően alkalmazott teljesítményértékelő és visszajelző rendszer hosszútávon nagymértékben hozzájárul mind a munkavállalók, mind a 
vállalat sikerességéhez és eredményességéhez. A kutatás és a szakirodalmi következtetések okán is megállapítható, hogy teljesítményértékelésre, visszajelzésekre szükség van, ám nem mindegy milyen módon, milyen gyakorisággal történik, és az sem, hogy ki adja át a teljesítménymérés során keletkezett információt a munkavállalónak, a szervezet dolgozójának. Jelen eredmények további kutatási irányokat is felvetnek, például a teljesítményértékelés gyakorisága és a fluktuációs mutató összefüggéseit, vagy a fejlesztésre, képzésre hajlandóság növekedését. A teljesítményértékelés több HR funkcióra van hatással, így a kapcsolódási pontok kutatása minden esetben hasznos visszajelzés lehet szervezeti oldalról is.

\section{Köszönetnyilvánítás}

„Az Innovációs és Technológiai Minisztérium ÚNKP-20-3 kódszámú Új Nemzeti Kiválóság Programjának a Nemzeti Kutatási, Fejlesztési és Innovációs Alapból finanszírozott szakmai támogatásával készült."

\section{Felhasznált irodalom}

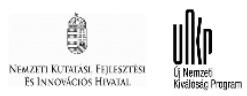

Alam, M. D., Latham, D. S. (2020): 'It is not my fault': Employee response to negative performance feedback. Organizational Dynamics, 49 (2): 1-8.

Baruch, Y., Peiperl, M. (2000): Career management practices: An empirical survey and implications. Human Resource Management, 39: 347-366. https://doi.org/10.1002/1099050X(200024)39:4<347::AID-HRM6>3.0.CO;2-C

Bálint B., Karoliny Zs. (2017): The more is applied, the better results are reached? Empirical lessons learned from the usage of career management tools. International Journal of Strategic Management and Decision Support Systems in Strategic Management, 22 (4): 3-10.

Canton, J. (2013): Global Futures Forecast 2013: The Top Trends That Will Shape the Coming Year. Institute for Global Futures.

Dajnoki K., Filep R. (2020): A teljesítménymérés módszerei a KKV szektorban. Jelenkori társadalmi és gazdasági folyamatok, 15 (3-4): 55-64.

Dajnoki K., Héder M. (2017): „Új szelek fújnak” - a HR válasza a globalizáció és a változás kihívásaira. Hadtudomány: A Magyar Hadtudományi Társaság Folyóirata, 2017. évi elektronikus lapszám (27): 84-93. https:doi.org/10.17047/HADTUD.2017.27.E.84

Dajnoki K., Kun A. I. (2016): Frissdiplomások foglalkoztatásának jellemzői az agrárgazdaságban. Gazdálkodás, 60 (4): 289-304.

Dajnoki K., Pierog A., Vörös P. (2015): Képzési-fejlesztési lehetőségek eredményességének megítélése megváltozott munkaképességü személyeket foglalkoztató szervezeteknél. Acta Scientiarum Socialium, 43: 57-66.

Erdei P., Fenyves V., Dajnoki, K. (2017): A munkahelyi elköteleződés felmérése és fejlesztési célok meghatározása. Taylor Gazdálkodás- és szervezéstudományi folyóirat, 9 (2): 107-113.

Fajcikova, A., Urbancova, H., Kucirkova, L. (2018): Decisive Factors of talent management implementation in Czech organisations. Journal of Efficiency and Responsibility in Education and Science, 11 (1): 9-15.

Gergely É. (2016): A teljesítménymenedzsment funkcionális jellege. International Journal of Engineering and Management Sciences (IJEMS)/ Müszaki és Menedzsment Tudományi Közlemények, 1 (1): 1-11. https://doi.org/10.21791/IJEMS.2016.1.20.

Gergely É., Pierog A. (2018): A tehetség megtartásának lehetőségei a karrierigények tükrében. International Journal Of Engineering And Management Sciences / Müszaki és Menedzsment Tudományi Közlemények, 3 (3): 31-43. 
Gyökér I., Finna H. (2007): Teljesítménymenedzsment. Oktatási segédanyag közgazdász hallgatók számára, Budapesti Műszaki és Gazdaságtudományi Egyetem Menedzsment és Vállalatgazdaságtan Tanszék, Budapest.

Héder M., Szabó Sz., Dajnoki, K. (2018): Effect of Labour Market Changes on HR Functions. Anali Ekonomski Fakulteta U Subotici / The Annals of the Faculty Of Economics Subotica, 54 (39/2018): 123-138.

HRportál (2017) <https://www.hrportal.hu/hr/a-munkavallalok-15-szazaleka-elkotelezettmunkahelye-irant-20181220.html $>(2021.01 .04$.)

Istók N. (2019): Több mint hüség. Az elköteleződés nem az évek számában mérhető. $<$ http://hrpwr.hu/megtartas/cikk/az_elkotelezodes_nem_az_evek_szamaban__ merheto> (2020.12. 15.)

Kiss Zs., Barizsné H. E. (2018): A munkahelyi elégedettség és a szakmai illeszkedés kapcsolata fiatal diplomások körében. In: Tóth, Dorina Anna (Szerk.) Az Oktatás Gazdagsága: Tanulmányok Polónyi István Tiszteletére. Debreceni Egyetem, Debrecen. 81-94.

Koncz K. (2013a): A sikeres szervezeti karrierfejlesztés feltételei. Munkaügyi Szemle, 57 (4): 32-43.

Koncz K. (2013b): Karriermenedzsment. Budapesti Corvinus Egyetem, Budapest.

Krajcsák Z. (2018): Az alkalmazotti elkötelezettség relatív fontossága a munka megváltozó világában. Vezetéstudomány/Budapest Management Review, 49 (2): 38-44.

Kubiak, E. (2020): Increasing perceived work meaningfulness by implementing psychological needsatisfying performance management practices. Human Resource Management Review. https://doi.org/10.1016/j.hrmr.2020.100792

Lee, Y., Kim, J. (2021): Cultivating employee creativity through strategic internal communication: The role of leadership, symmetry, and feedback-seeking behaviors. Public Relations Review, 47 (1): 2-11. https://doi.org/10.1016/j.pubrev.2020.101998

Lewis, S., Arnold, J. (2012): Organisational career management in the U.K. retail buying and merchandising community. International Journal of Retail \& Distribution Management, 40 (6): 451-470.

Li-Ying, J., Zhang, Z., Long Q. (2018): An alternative way to make knowledge sharing work in online communities? The effects of hidden knowledge facilitators. Management and Organization Review, 14 (4): 781-825. https://doi.org/10.1017/mor.2018.48

Orphen, C. (1994): The effects of organisational and individual career management on career success. International Journal of Manpower, 15 (1): 27-37.

Pató G.-né Szücs B., Illés K. (2018): Az emberközpontú munkaköri leírás. Hadtudomány: A Magyar Hadtudományi Társaság $\quad$ Folyóirata, $28 \quad$ (2): $107-117$. https://doi.org/10.17047/HADTUD.2018.28.2.107

Piac és profit (2020) <https://piacesprofit.hu/kkv_cegblog/hol-a-legjobb-dolgozni-ezek-a-cegek-alegvonzobb-hazai-munkaadok/2/> (2021.01.04.)

Pierog A., Gergely É., Dajnoki, K. (2018) Vezetőkkel szembeni kompetencia elvárások. In: Dobrai K., László Gy., Sipos N. (szerk.): Farkas Ferenc Nemzetközi Tudományos Konferencia, Pécs, Magyarország. Pécsi Tudományegyetem Közgazdaságtudományi Kar Vezetés- és Szervezéstudományi Intézet (1). 478-492.

Pirohov-Tóth B. (2019): Role of Management in The Effect on Employee Motivation of Organizational Performance - Hungarian Case Study. Journal of Social and Political Sciences, 2 (2): 246-252.

Szabó-Bálint B. (2018): A munkavállalói siker és az elérését támogató szervezeti karriermenedzsment-eszközök. Vezetéstudomány/Budapest Management Review, 49 (10): 8592.

Szabó-Bálint B., Karoliny M.-né (2019): A karriersiker titka, avagy a siker elérését befolyásoló tényezők. In: László Gy., Németh J., Sipos N. (szerk): Vezetö és menedzser. Emlékkötet Farkas Ferenc születésének 70. évfordulója alkalmából. Pécsi Tudományegyetem, Közgazdaságtudományi Kar. Pécs. 166-173.

I1: <psycho.unideb.hu/munkatarsak/balazs_katalin/stat1/stat1ora3.pdf> (2021.01.05.) 